\title{
The British Relief Association and the Great Famine in Ireland
}

L'association britannique de secours et la grande famine irlandaise

\section{Christine Kinealy}

\section{(2) OpenEdition \\ 1 Journals}

Electronic version

URL: http://journals.openedition.org/rfcb/230

DOI: $10.4000 / \mathrm{rfcb} .230$

ISSN: 2429-4373

\section{Publisher}

CRECIB - Centre de recherche et d'études en civilisation britannique

\section{Printed version}

Date of publication: 1 September 2014

Number of pages: $49-66$

ISSN: 0248-9015

\section{Electronic reference}

Christine Kinealy, "The British Relief Association and the Great Famine in Ireland », Revue Française de Civilisation Britannique [Online], XIX-2 | 2014, Online since 01 May 2015, connection on 21 December 2020. URL : http://journals.openedition.org/rfcb/230 ; DOI : https://doi.org/10.4000/rfcb.230

\section{cc) (D) $\ominus$}

Revue française de civilisation britannique est mis à disposition selon les termes de la licence Creative Commons Attribution - Pas d'Utilisation Commerciale - Pas de Modification 4.0 International. 


\title{
The British Relief Association and the Great Famine in Ireland
}

\author{
Christine KINEALY \\ Director of Ireland's Great Hunger Institute, Quinnipiac University
}

Private charity played an important role in saving lives during the Great Famine. While the first appearance of the potato blight in 1845 resulted in some sporadic fund-raising activities, it was the second, more widespread appearance of disease in 1846 that triggered international fund-raising efforts on an unprecedented scale. A number of committees, which had been active during the earlier subsistence crises of 1822 and 1831 , were revived at the end of 1846 , but it was the scale and severity of the second potato failure that encouraged a number of new bodies to come into existence. ${ }^{1}$ The largest, and ultimately the most successful, was the British Association for the Relief of Distress in Ireland and the Highlands of Scotland.

The first official meeting of the British Association took place on 1 January 1847 at St Swithin's Lane in London, the premises of the banker and noted philanthropist, Baron Lionel de Rothschild. Subsequent meetings were held in South Sea House on Threadneedle Street, the commercial and banking hub of the British Empire. Rothschild had been motivated to become involved in Irish famine relief following the publication in the London Times, on 24 December, of a letter written by Nicholas Cummins, a Justice of the Peace in Cork, describing a recent visit to the district of Skibbereen. The letter had been addressed to the Irish-born Duke of Wellington, 'without apology or preface', but Cummins asked that it be forwarded to Queen Victoria, on the grounds that, 'She is a woman, she will not allow decency to be outraged. She has at her command the means of at least mitigating the suffering of the wretched survivors in this tragedy'. Cummins went on to say:

... the scenes that presented themselves were such no tongue or pen can convey the slightest idea of ... such frightful spectres as no words can describe. By far the greater number was delirious, either from famine or fever. Their demonic yells are still yelling in my ears, and their horrible images are fixed upon my brain ... The same morning the police opened a house on the adjoining lands, which was observed shut for many days, and two frozen corpses were found lying upon the mud floor half devoured by the rats. ${ }^{2}$

\footnotetext{
${ }^{1}$ See Christine KINEALY, Charity and the Great Hunger in Ireland. The Kindness of Strangers, London: Bloomsbury, 2013.

${ }^{2}$ Times, 24 December 1846.
} 
The humanitarian appeal of the letter did not fail - although it was, perhaps ironically, a small group of English bankers and merchants who used it as a call to action. Within days, they had contributed $£ 10,000$ to famine relief and, led by Rothschild, had established a committee to act as a channel for others who wanted to help.

\section{The Committee of the British Association}

London banks were a vital lubricant in the smooth running of the vast British Empire, and the men present at the first meeting of the British Association represented some of the most influent banking houses in the world. It included Lionel de Rothschild and his brother Mayer de Rothschild, who were at the centre of a family network of international financiers. They were joined by John Abel Smith and George Robert Smith, both partners in Smith, Payne and Smiths Bank; Henry Kingscote, former Director of Ladbroke, Kingscote and Co.; William George Prescott of Prescott and Grote of Threadneedle Street; and the Honorable Stephen Spring Rice of the Board of Customs. ${ }^{3}$ Each of these men had donated $£ 1,000$ towards famine relief.* The committee quickly expanded to include Samuel JonesLoyd of Jones, Loyd and Co., Robert Hanbury of Truman, Hanbury, Buxton and Co., Raikes Currie of Curries and Co. Bank, and Thomas Baring of Baring Brothers and Co. On 6 January, David Salomons, a success banker and member of the London Stock Exchange, joined the committee of the British Association. ${ }^{4}$ Salomons, a champion of 'Jewish Emancipation', was notable for having been the first Jewish Sheriff of the City of London and the first Jewish Lord Mayor of London. $^{5}$ The current Lord Mayor of London, John Kinnersley Hooper, was also invited to be part of the committee. Hooper was a member of 'The Honorable Irish Society', which had been established in the early seventeenth century to assist in the Plantation of Ulster. Hooper had visited Ireland on the society's behalf in the 1830s. ${ }^{6}$ Overall, this small committee included some of the most powerful banking families in the United Kingdom - and thus in the British Empire. In addition to contributing financially, over the next 18 months, these men were to give a considerable investment of their time, with the committee meeting as frequently as six afternoons a week. ${ }^{7}$

The British Association had strong political connections, mainly with the Whig Party, which had been in power since June 1846. Raikes Currie had served as a Whig politician since 1837. John Abel Smith, a close friend of Lionel de Rothschild, was Whig MP for Chichester, while George Robert Smith represented

*A note on currency: a pound (£) was made up of 20 shillings (s) and 240 pence (d). $£ 1$ in 1847 was equal to approximately $£ 100$ today.

${ }^{3}$ F. Carleton and John Cummins were also present. Minutes of British Relief Association (BRA), National Library of Ireland (NLI), Ms. 2022, 1 January 1847, p. 1.

${ }^{4}$ Ibid., 6 January 1847, p. 15.

${ }^{5}$ Albert Montefiore HYAMSON, David Salomons, London: Methuen, 1939.

${ }^{6}$ Report of the Deputation Appointed by the Honorable the Irish Society to Visit the City of London's Plantation in Ireland in the Year 1836. London: C. Skipper and East, 1836, p. 118.

7 They met on Mondays to Saturdays at $2.00 \mathrm{pm}$. Their commitment was especially remarkable given that 1847 was associated with a banking 'crisis', culminating in the autumn. 
Buckinghamshire. ${ }^{8}$ Lionel de Rothschild, who had brought the committee together, was a friend of the Prime Minister, Lord John Russell, and a supporter of the Whig Party. ${ }^{9}$ Rothschild's own political ambitions, however, would be repeatedly thwarted because, although elected on a number of occasions, including in 1847, as a Jew, he was unable to take an oath allowing him to sit in the British parliament. ${ }^{10}$

Thomas Baring was also an MP, but supported the Tory Party. He had firsthand knowledge of providing relief. Following the first appearance of potato blight, his company had been commissioned secretly by Sir Robert Peel's government to import $£ 100,000$ worth of overseas' grain to Ireland in order to control food prices during the scarcity. Barings' involvement had ended in August 1846 when the role was taken over by Eric Erickson and Company, of Liverpool. ${ }^{11}$ In 1847 , however, the Baring and Rothschild companies were commissioned by the British government to raise $£ 8$ million to fund future expenditure on famine relief. Baring had declined payment for either task. ${ }^{12}$

The potato blight had also appeared in the Highlands of Scotland in 1845 and it returned, more severely, in 1846. Consequently, the Association decided to apportion one-sixth of its funds to provide assistance there. To look after Scottish needs, the Earl of Dalhousie and Arthur Kinnaird were recruited to the committee, their remit being to work with agencies already estblished in Glasgow and Edinburgh. ${ }^{13}$ To look after Irish relief, the committee appointed Jones-Loyd as chairman and Spring Rice as Honorary Secretary. Spring Rice was one of only two Irish-born men on the committee. ${ }^{14}$ While not a politician himself, he was wellconnected through his father, Lord Monteagle, also a Whig politician, who had served as Chancellor of the Exchequer from 1835 to 1839 and as Comptroller General since 1839. He had chosen not to follow his father into politics but, by background and training, he was well suited to take a lead role in the British Association. The Spring Rice family owned large estates in counties Limerick and Kerry and so he had first-hand knowledge of the impact of the potato failures on the Irish poor. Since 1845 , both father and son had been directly involved in providing employment and relief for their tenants. ${ }^{15}$ Following the second appearance of blight, Lord Monteagle had written to the British government, apprehensive of the

${ }^{8}$ Smith, a personal friend of Rothschild, was a supporter of Jewish Emancipation; see Harry Tucker EASTON, The history of a banking house: Smith, Payne and Smiths, London: Blades, East \& Blades, 1901, pp. 25-27.

${ }^{9}$ Isidore SINGER and Cyrus ADLER, The Jewish Encyclopedia: A Descriptive Record of the History, Religion, Literature, and Customs of the Jewish People from the Earliest Times to the Present Day, New York and London: Funk and Wagnalls, 1916, vol. 10, p. 502.

${ }^{10}$ As a Jew, Rothschild was unable to take the Oath of Allegiance. This situation did not change until 1858 when he became the first Jewish MP in the British House of Commons.

${ }^{11}$ The Baring Archive, London, HC 15 A. 2, 1846-48.

${ }^{12}$ Ibid.

${ }^{13}$ Minutes of BRA, 5 January 1847, p. 12.

14 The other Irish member was James John Cummins, uncle of Nicholas, and a Cork-born banker who worked in London.

${ }^{15}$ Monteagle Papers, NLI, Ms. 13,395/5; during an earlier subsistence crisis, Lord Monteagle had published, 'Hints on the best mode of relieving the distress existing in certain districts of Ireland from the failure of the potato crop' by Thomas Spring Rice (1822). 
'magnitude of the existing calamity and its danger not being fully known and appreciated in Downing Street'. Charles Trevelyan, Permanent Assistant at the Treasury, who, de facto, had been overseer of government relief since 1845, assured him that, 'The government establishments are strained to the utmost to alleviate this great calamity and avert this danger, as far as it is in the power of government to do so. ${ }^{16}$ As disease spread and mortality mounted in the final months of 1846 , these words appeared increasingly hollow.

The formation of the London committee was welcomed in Ireland. Nicholas Cummins, the Cork Justice of the Peace, who had written the initial appeal to the Duke of Wellington, wrote to Irish newspapers that, 'I have unbounded satisfaction in being able to assure you of the glorious fact that nine names alone in London have this day subscribed for the truly noble amount of $£ 8000$. Surely her merchants are princes and her traders the most honourable on the earth ${ }^{17}$ The Association also won the praise of a young Quaker philanthropist, William E. Forster, who had travelled with his father to Connemara in the winter of 1846-47. He observed approvingly, 'Rothschild, Kinnaird and some dozen other millionaire city princes meeting every day, and working hard. A far greater sacrifice to them than mere gifts of money'. ${ }^{18}$

Within days of being formed, the Association was receiving requests for financial support from organizations in Ireland, including several ladies' committees, as far apart as Dublin and Kerry. ${ }^{19}$ On 4 January, the committee received a report on conditions in Skibbereen, the town that had prompted Cummins's letter and which was becoming a metaphor for suffering in Ireland. The Committee decided to act immediately and to obtain a ship to take food to Ireland. ${ }^{20}$ They were helped by the donation of a steam-ship, the Tar, for their immediate use, by the Peninsular and Oriental Company. ${ }^{21}$ This was followed by the North Western, the Great Western, and the South Western Railways offering free carriage to all Association relief going to Ireland. ${ }^{22}$ The Association's main targets for assistance were those who were beyond the reach of government, in particular, fatherless children and widows. The aid was to be given in, 'food, clothing and fuel but in no case shall money be given to the parties relieved'. ${ }^{23}$ This dictum proved short-lived, however; as the reality of the suffering and the needs of the poor became evident, relief was provided in money by the Association's agents.

In order to make the most efficient use of their resources, the London committee chose to work closely with the British government. This enabled them to channel their aid through the existing local relief committees. Additionally, it meant that the Association became the recipient of the monies that were being raised by

${ }^{16}$ C. E. Trevelyan to Lord Monteagle, 9 October 1846. Monteagle Papers, NLI, Ms.13,397 /1.

${ }^{17}$ Tuam Herald, 9 January 1847.

18 Niall FERGUSON, The House of Rothschild: Money's prophets, 1798-1848, London: Penguin, 1999, p. 443.

${ }^{19}$ Minutes of BRA, 1 January 1847 , pp. 10-22.

${ }^{20}$ Ibid., 4 January 1847 , p. 10.

${ }^{21}$ London Standard, 21 January 1847.

${ }^{22}$ Western Times (Devon), 30 January 1847.

${ }^{23}$ Minutes of BRA, 1 January 1847, pp. 2-3. 
municipal bodies in England and through local governments elsewhere in the Empire. Ultimately, this arrangement proved to be particularly beneficial to government administrators in Ireland who, on numerous occasions, relied on the resources of the Association to support their own, inadequately-funded and centrally-determined, relief measures. This relationship also meant working with Charles Trevelyan of the Treasury. Trevelyan was part of the Clapham Sect, a network of evangelical MPs and other influential figures who viewed the Famine through a providentialist prism. Trevelyan, helped by the presence of his friend and fellow evangelical Henry Kingscote on the committee, did try to impose his moralist view of how relief should be given by the British Association. ${ }^{24}$ The presence of the Rothschilds and David Salomans on the committee, together with the administrative skills and firm guidance of Spring Rice, its Secretary, provided an important counter-balance to Trevelyan's meddling. Moreover, Trevelyan's doctrinaire and domineering style of management was to alienate the relief officials who worked with him, including Count Strzelecki, the Association's agent in Ireland. ${ }^{25}$ Spring Rice's frustration with the overly-bureaucratic approach regarding the giving of government relief was evident in a letter to Trevelyan dated 26 February, when he requested that the Association be allowed to make immediate use of food in government stores, offering instant payment in return. He explained that this action would obviate 'the various difficulties which stand in the way of effecting as rapid a supply of food to the distressed districts of Ireland as is undoubtedly desirable, and as the amount of funds at their disposal would justify'. ${ }^{26}$ Trevelyan agreed to this request. This exchange between the British Association and the Treasury revealed that the British government did have supplies of food available in Ireland, but that despite evidence of suffering and death - it was unwilling to ultilize them. It was the intervention of private charity, in this case, the British Association, which released the food to the poor.

\section{Getting relief to the Irish Poor}

On 20 January 1847, Jones-Loyd, mentioned that his friend, 'Count Strelitzski [sic], a Polish gentleman of extensive travel had offered his personal services gratuitously to Ireland with a view of being useful to the committee' ${ }^{27}$ Polish-born Pawel (Paul) de Strzelecki was a noted explorer of Australia and a scientist. In 1845, he had become a naturalized British subject, with Jones-Loyd as one of his sponsors. Strzelecki's offer was accepted and he was asked to leave immediately for Dublin to meet with Sir Randolph Routh, chairman of the Relief Commission. ${ }^{28}$ He then proceeded to counties Donegal, Mayo and Sligo, to report on the condition of the

${ }^{24}$ Peter GRAY, 'National Humiliation and the Great Hunger: Fast and Famine in 1847', Irish Historical Studies, Vol. 32, November 2000, p. 198.

${ }^{25}$ See Christine KINEALY, A Death Dealing Famine: The Great Hunger in Ireland, London: Pluto Press, 1997, p. 138. (The Earl of Clarendon, Lord Lieutenant of Ireland after 1847, privately coined the word 'Trevelyanisms'.)

${ }^{26}$ Honorable Spring Rice to Trevelyan, 26 February 1846 - [sic] it should be 1847 -, Correspondence relating to the measures adopted for the relief of the distress in Ireland, Jan. to March 1847, British Parliamentary Paper (BPP, 1847, vol. 52), Board of Work Series, p. 177.

${ }^{27}$ Ibid., 20 January 1847 , p. 72.

${ }^{28}$ Ibid., 21 January 1847, p. 75. 
population and to distribute a cargo of food on behalf of the Association. ${ }^{29}$ Upon arrival in County Mayo, Strzelecki chose Westport as his base. He reported to the London committee:

No pen can describe the distress by which I am surrounded. It has actually reached such a degree of lamentable extreme that it becomes above the power of exaggeration and misapprehension. You may now believe anything which you hear and read, because what I actually see surpasses whatever I read of past and present calamities. ${ }^{30}$

Strzelecki's powerful eye-witness testimony was reprinted in many newspapers throughout Britain and provided an important counter-balance to reports in the press suggesting that the suffering had been exaggerated. ${ }^{31}$ Some accounts suggested that the poor would rather starve than stop making donations to Daniel O'Connell's Repeal Association. As one letter to the London Standard explained:

[the speeches] are eminently calculated to negative your forcible appeals in favour of the sufferers from famine and to harden the hearts of the people of England. If the Irish poor are in such a state of priestridden idiocy as to prefer starvation to the with-holding of their miserable pence from the grasp of the vile demagogue to whom they have subjected themselves, who can help them? ?2 $^{32}$

Regardless of bad weather and poor infrastructure, by 1 March 1847 Strzelecki had provided relief in 65 localities, distributing 30 bales of clothing, 1,020 bags of rice and 1,905 barrels of Indian meal. To ensure efficient and prompt distribution, he had employed two constables as his assistants, informing the London committee that the expense was 'unavoidable. ${ }^{33}$ In early spring, as the government's public work scheme started to close, arbitrarily and without regard to local needs, demands made on the British Association increased. By 1 April 1847, Strzelecki had spent $£ 2,953$ in County Mayo, $£ 1,740$ in County Donegal, and $£ 1,193$ in County Sligo. ${ }^{34}$ Even at this early stage, government officials were unequivocal about their debt to Strzelecki and the British Relief Association. In Westport, where an estimated 8,000 persons were being fed weekly from Association grants, the local Poor Law Officer acknowledged:

To them [the BRA] this union owes a debt of gratitude, for this as well as the many grants made to them during the last three months; and to you I am personally under great obligation, for putting at my disposal so effective a stimulant to the several Committees to commence the

\footnotetext{
${ }^{29}$ Ibid., 22 January 1847 , p. 80.

${ }^{30}$ Ibid., 1 February 1847 , p. 111.

${ }^{31}$ For example, Western Times (Devon), 6 February 1847.

${ }^{32}$ London Standard, 19 January 1847.

${ }^{33}$ Strzelecki, Westport, 1 March 1847, Report of British Relief Association for the Relief of Distress in Ireland and the Highlands of Scotland (Report of BRA), London: Richard Clay, 1849, p. 94.

${ }^{34}$ Ibid., Strzelecki, Westport, 5 April 1847, p. 99.
} 
new system of relief. Pray convey my acknowledgement to your truly benevolent Association. ${ }^{35}$

Working so closely with the poor took its toll on Strzelecki's health and, in April, he contracted typhoid fever. Although he survived, he never returned to full health. ${ }^{36}$

To cope with what was clearly a nationwide crisis, the Association appointed more agents to travel to Ireland, while making Strzelecki their Executive Director. The first of these volunteers was Lord Robert Clinton who was put in charge of counties Galway, Clare, Limerick and Kerry. ${ }^{37}$ A few weeks later, he was joined by Lord James Butler, whose family owned Kilkenny Castle. ${ }^{38}$ Both men were in their 20s and they had offered their services gratuitously. Matthew Higgins, an Irish-born writer who was best-known for writing polemical articles in the British press under the pseudonym Jacob Omnium, also offered his services to the British Association. He asked to be based in the remote region of Belmullet in County Mayo, an area which was gaining the same grim notoriety as Skibbereen in County Cork due to accounts of the suffering and mortality of its people. ${ }^{39}$ When Higgins arrived there, he was shocked by what he witnessed: 'The streets are full of people in a dying state; at every corner one hears horrible accounts of bodies found in ditches and on dung heaps'. He believed that the local deaths and disease 'equal the worst details from Skibbereen'. ${ }^{40}$ Higgins, like Strzelecki, was particularly touched by the plight of the children: 'I cannot express to you how painful it is to witness the wretched children, actually expiring in the streets, and to be debarred from assisting them; but if I were to do so once, I could not walk about the town'. ${ }^{41}$

Higgins left Belmullet on 4 May. During his short stay, he had helped to establish soup kitchens throughout the district. ${ }^{42}$ Despite all that he had done to help the local people, Higgins's final letters were dejected in tone. In them, he made a special plea for the district he was leaving, asking that this region should 'be made an exception to the general relief measures'. ${ }^{43}$ Higgins received neither compensation nor lasting recognition for the time he spent in County Mayo, but, like Strzelecki, he had not only saved lives, he had given a voice and dignity to people who had been forsaken by their government, their landlords and their religious ministers.

The failure of the public works to save lives led to a temporary relief measure being introduced in spring 1847 which provided for free food in the form of soup

${ }^{35}$ Ibid., Richard M. Lynch to Strzelecki, Westport, 24 April 1847, p. 104.

${ }^{36}$ Strzelecki to Adyna, 5 June 1851, quoted in Geoffrey RAWSON, The Count. A Life of Sir Paul Edmund Strzelecki, K.C.M.G. Explorer and Scientist, Melbourne: William Heinemann, 1953, p. 173.

${ }^{37}$ Report of BRA, 17 February 1847, p. 162.

${ }^{38}$ Ibid., 1 March 1847, p. 95.

${ }^{39}$ Ibid., 19 March 1847, p. 241.

${ }^{40}$ Ibid., Report of Higgins, Belmullet, 8 April 1847, p. 108.

${ }^{41}$ Ibid., p. 111.

${ }^{42}$ Ibid., pp. 21-22.

${ }^{43}$ Ibid., Higgins, Belmullet, 29 April 1847, p. 116. 
being given to the poor. By summer 1847, Ireland was covered by a network of soup kitchens which was feeding over three million people a day - an incredible logistic feat and proof of the ability of the government to provide adequate relief. At this point, the British Association decided to wind down its own operations and, by the end of June, all of their agents, with the exception of Strzelecki, had been withdrawn from Ireland. However, during the transition period from one system of government relief to another, there was much hardship and, again, the Association intervened to support the poor who were without relief. ${ }^{44}$

\section{Feeding the Children}

In the autumn of 1847, the British government announced that the Famine was over and that all future relief should come from Irish, and not British, nor even imperial, taxation. In effect, this meant that the workhouse system, funded through local taxation, would have to both provide and finance all government relief. At this stage, most charities had ceased operating as their funds were exhausted. There was a mistaken belief that further assistance was unnecessary. The exceptions to this were the Society of Friends and the British Relief Association whose charitable work continued into 1848 .

Inevitably, the role of Strzelecki changed, as he was now the only agent of the British Association remaining in Ireland. He worked closely with Poor Law officials, using the residual funds of the Association to support the 22 Poor Law Unions that had been officially declared 'distressed'. The Association had offered Strzelecki's services in recognition that, 'the transition from the one system to the other, it was obvious, would be attended with considerable difficulty, out of which much additional pressure of a temporary character might probably arise. ${ }^{45}$ Again, private charity was being called on to provide essential relief when the government was failing to do so.

Since arriving in Ireland an abiding concern of Strzelecki's had been with how children were faring as the family unit and other social structures broke down. In the spring of 1847, Strzelecki pioneered a system of feeding schoolchildren in the Westport Union, giving each child clothing and one meal a day, at a daily cost of one-third of a penny. Before being fed, each child was required to wash their face and hands, and to comb their hair. ${ }^{46}$ Apart from the advantages to the children, the parents also benefited from not having to share their scant resources. The scheme was widely praised: the local Board of Guardians in Westport, under the chairmanship of Lord Sligo, passed a vote of thanks to the Association and to Strzelecki on behalf of the children, for 'not alone relieving their physical wants, but extending the blessings of education, so necessary for the well-being of society'. ${ }^{47}$ Strzelecki's efforts were also applauded in the local press, the Tyrawly Herald

\footnotetext{
${ }^{44}$ See Kinealy, Kindness of Strangers, op. cit., chapter 8.

${ }^{45}$ Report of BRA, p. 29.

${ }^{46}$ Ibid., Regulations regarding relief through Schools, November 1847, Appendix D, pp. 18687.

${ }^{47}$ Ibid., Resolution of Westport Union, 16 September 1847.
} 
opining that the children's 'pure hearts should glow with gratitude at this fresh proof of the concern entertained for their comforts by their generous benefactors'. ${ }^{4}$

The success of the scheme encouraged Strzelecki to ask the committee in London if he could extend his scheme to other unions. His appeals on behalf of the children became more urgent following the transfer to Poor Law relief, he fearing that 'the actual and future effects which the physical and moral degradation to which they are exposed, through hunger and nakedness, has and will have on the country'. ${ }^{49}$ With the approval of the Treasury, in the winter of 1847 , the scheme was extended to the 22 distressed unions. As a result, for almost nine months, over 200,000 children received free rations of food daily and appropriate clothing. The scheme finally ended in July 1848 when the funds of the British Association were totally exhausted. Despite assurances to Strzelecki by the Prime Minister that the scheme would continue at public expense, the Treasury refused to take over financial responsibility for feeding the children. ${ }^{50}$

\section{The Donors}

While members of the London committee provided the initial funding for the work of the British Association, the early demands made on them for charitable support made further fund-raising necessary. Approval for their work by the British Establishment was quickly evident. Within days of being formed, the Association was informed by the Prime Minister that Queen Victoria was 'pleased to order her name to be inserted as a donor of two thousand pounds towards the object of the fund ${ }^{51}$ The following day, they received $£ 500$ from Prince Albert. ${ }^{52}$ Other royal donations followed. ${ }^{53} \mathrm{~A}$ few weeks later, the committee were informed that they were to be the beneficiary of the proceeds of a 'Queen's Letter' that was to be read in Anglican churches in Britain, calling for prayer and donations for Ireland. ${ }^{54}$ Encouraged by this validation, the Association sent a circular to people occupying high offices of state, including Peers and MPs, asking for contributions. A request for aid was also inserted in newspapers in Britain, with a similar appeal being made to British communities in India, Singapore and China. ${ }^{55}$ A separate notice asked for cast-off clothing. ${ }^{56}$ Many British politicians responded, including the former Prime Minister, Sir Robert Peel (£200), his successor, Lord John Russell (£300), Benjamin D'Israeli, a Christianized Jew and friend of the Rothschilds (£21), William Gladstone, then a member of the Tory Party (£50), and Sir Charles Wood,

${ }^{48}$ Tyrawly Herald, 20 April 1847.

${ }^{49}$ Regulations regarding relief through Schools, November 1847, pp. 186-87.

${ }^{50}$ Memorandum by Lord John Russell, National Archives of England, T.64/367 B, 30 April 1848.

${ }^{51}$ Minutes of BRA, 4 January 1847 , p. 7. Queen Victoria had initially donated $£ 1,000$ but, at Spring Rice's insistence, it was raised to $£ 2,000$.

${ }^{52}$ Ibid., 5 January 1847 p. 11.

${ }^{53}$ Contributions', Report of the BRA. Unless otherwise stated, details of donations are taken from this source.

${ }_{54}^{54}$ Minutes of BRA, 13 January 1847, p. 45

${ }^{55}$ Ibid., 4 January 1847 , pp. 8-9.

${ }^{56}$ Ibid., 5 January 1847, p. 12. 
Chancellor of the Exchequer (£200). Charles Trevelyan also made a donation of $£ 50$.

In the months that followed, donations poured into the British Association on a scale that was unprecedented and, even to the committee, unexpected. The donors came from all parts of the world, from all religious denominations, from all social and economic classes, and cut across gender and ethnic divisions. Inevitably, the motives varied greatly. Over 15,000 individual contributions were recorded by the British Association, and their note-keeping reflects the professionalism and diligence that was a hallmark of the committee.

Donations from religious bodies reflected the ecumenical nature of the committee itself. Through the formal mechanism of two 'Queen's Letters', the British monarch had appealed to Anglicans in the United Kingdom in March and October 1847. They had raised approximately $£ 170,000$ and $£ 30,000$ respectively, which had been entrusted to the British Association. Less high-profile interventions included one from a Moravian Chapel in Fairfield near Manchester, which raised $£ 11$, the proceeds of a fast. The German Lutheran Church in the Strand in London gave £22.16s.6d. The High Pavement Chapel in Nottingham, which was a stronghold of the Society of Protest Dissenters and known for its charitable and educational work, donated £56.6s.6d. ${ }^{57}$ The Unitarian Meeting House in Birmingham raised $£ 106.4 \mathrm{~s} .5 \mathrm{~d}$. The Presbyterian Church in Brampton, Cumbria, collected £1.1s.0d, while St Clements' Catholic Church in Cambridge gave $£ 21$. Religious bodies overseas also donated with contributions coming from synagogues and Shaker communities, amongst others. The donations to the British Association reflected the ecumenical nature of the committee itself, and, more importantly, its commitment to providing non-sectarian charity.

Regardless of the fact that the British economy was undergoing an industrial recession after 1847 , with high unemployment in many towns and cities, numerous committees were formed to raise money for the Irish poor. ${ }^{58}$ The largest single donation came from a committee in the adjoining cities of Manchester and Salford, an area at the centre of Britain's industrial revolution. Regardless of a severe downswing in trade and high unemployment, it raised $£ 7,785$. Some of the most privileged members of society donated to Ireland. This included numerous donations from the University of Oxford, which was an Anglican institution, although a number of its theologians were controversially involved with a movement to return to the traditions of the Catholic Church. Students were amongst those who contributed. From Balliol College, H. Lopez gave £2, E.S. Parry Esq., H.H. Parry Esq., and S. S. Vaughan Esq., each donated £1. George Ridding, then a 19-year-old student also at Balliol, gave £1. Ridding went on to have an illustrious career which included being appointed Headmaster of Winchester College and the first Bishop of

57 Records of High Pavement Presbyterian (Unitarian) Chapel, Nottingham, 1576-1982, University of Nottingham: $<$ http://longford.nottingham.ac.uk/Dserve/dserve.exe?dsqIni=Dser ve.ini\&dsqApp $=$ Archive $\& d s q D b=$ Catalog $\& d s q S e a r c h=\% 28$ PersonCode $==\mathrm{NA336} \% 29 \& d s q$ Cmd=Show.tcl $>$ [accessed 9 June 2013].

58 The despair and poverty of the English poor in these years is captured in Elizabeth Gaskell's Mary Barton, which was first published in 1848 and set in Manchester. 
Southwell. ${ }^{59}$ Charles Holbrow Stanton of Balliol College, who was President of the Oxford Union in 1847 , donated $£ 2 .{ }^{60} \mathrm{He}$ was succeeded in this position by the Earl of Dufferin, a student in Christ Church, who was to forge a close association with Skibbereen and raise money for the starving of that area. ${ }^{61}$ Balliol's lasting association with the Famine, however, was to be achieved inadvertently, in a remark allegedly made to Benjamin Jowett, then a young tutor, later to be Master of the College. The British economist Nassau Senior, no friend of the Irish poor, commented to Jowett that a million deaths in Ireland would 'scarcely be enough to do much good'. ${ }^{2}$

Donations to the British Association came from unexpected and unsolicited sources. A 'Mrs Lockett' of Brighton held an exhibition of her talking canary bird, which raised $£ 10.10$ s. Entertainment provided by the Elocution Society of the London Mechanics Institution, which had been founded in 1823 to provide education to working men, collected $£ 11.17 \mathrm{~s}$. The owner of a telescope located at the foot of Blackfriars Bridge in London raised 1s.10d., by allowing people to have 'sundry peeks at the Moon and Jupiter'. The Cogers Society, a 'Society of Thinkers' founded in 1755 - and of which the young Daniel O'Connell had been a member from 1794-96 - raised $£ 14$ from their meeting rooms in the White Bear Inn, near Fleet Street in London. ${ }^{63}$ More jovially, 'a few friends meeting' at the Granby Wine Rooms in Bedford Square, also in London, raised $£ 11$. Passengers on board the transatlantic ship, SS Cambria, which departed from Liverpool in February 1847, also donated. ${ }^{64}$ They included the diminutive performer 'General' Tom Thumb, who, with his manager, the impresario and circus owner, P. T. Barnum, had been travelling in England. During his visit, Tom Thumb had been a guest of Queen Victoria at Buckingham Palace. ${ }^{65}$ Another passenger on the Cambria, Irish-born explorer John Palliser, described his first encounter with Tom Thumb, who, 'creeping from under shawls and ladies' work-baskets, emerged into the saloon, stuck his Lilliputian hands into his little pockets ... he was the smallest specimen of human nature it has ever been my lot to behold' ${ }^{66}$ At this stage, Tom Thumb was 9 or 10 years old, although Barnum deliberately gave his age as older.

\footnotetext{
${ }^{59}$ Lady Laura RIDDING, George Ridding: schoolmaster and bishop, forty-third head master of Winchester, 1866-1884, first bishop of Southwell, 1884-1904, London: E. Arnold, 1908.

${ }^{60}$ Stanton trained as a barrister and later in life worked for the Charity Commission for England and Wales.

${ }_{61}$ Frederick Temple Blackwood DUFFERIN, Narrative of a Journey from Oxford to Skibbereen during the Year of the Irish Famine, Oxford: John Henry Parker, 1847.

${ }^{62}$ Quoted in Cormac Ó GRÁDA, Ireland Before and After the Famine: Explorations in Economic History, 1800-1925, Manchester University Press, 1993, p. 127.

${ }^{63}$ Daniel O'CONNELL, Daniel O'Connell: His Early Life, and Journal, 1795 to 1802, London: Pitman and sons, 1906, p. 66.

${ }^{64}$ The BRA records say passengers on the Cambria donated $£ 52-10$ s., but newspapers suggest it was higher.

${ }^{65}$ Tom THUMB, Sketch of the life: personal appearance, character and manners of Charles S. Stratton, the man in miniature, known as General Tom Thumb, and his wife, Lavinia Warren Stratton, including the history of their courtship and marriage, New York: S. Booth, 1874, p. 6.

${ }^{66}$ John PALLISER, Solitary rambles and adventures of a hunter in the prairies, London: J. Murray, 1853, pp. 2-3.
} 


\section{Overseas Donations}

Numerous donations to the British Association came from overseas, not only from the far-flung corners of the British Empire, but also beyond. People in the United States proved to be generous benefactors to the Irish poor, although the majority of their fund-raising efforts were channeled through the Society of Friends. One of the American donors recorded by the Association was Abraham Lincoln Esq., who donated $£ 5$. Lincoln, a young lawyer, had recently been elected to the U.S. House of Representatives. His assassination in 1865 would deprive the country of one of its most admired Presidents. Numerous donations came from the Province of Canada, also referred to as British North America. New Brunswick was in the forefront of these efforts, with the local Provincial House of Assembly voting $£ 1,500$ for the British Association. Multiple donations followed, leading the Earl of Elgin, the Governor-General, to inform the British Colonial Secretary on 28 May that he expected the final Canadian contribution to be no less than $£ 20,000$, which had been raised by people 'of all creeds and origins'. He pointed out that 'several of the Indian tribes have expressed a desire to share in relieving the wants of their suffering white brethren'. ${ }^{67}$

More unexpectedly perhaps, donations to the British Association came from India, Australia, China, South America, South Africa and the Caribbean (the British West Indies). The largest single collection was forwarded by the Bombay Relief Committee, which raised $£ 10,177.14 \mathrm{~s}$.8d. From the other side of the world, $£ 746.18 \mathrm{~s}$.9d. was received from the Bahamas, $£ 500$ coming from the Legislature in Nassau, given on behalf of both Ireland and Scotland. The local Assembly passed a motion explaining:

... with feelings of deep commiseration for the extreme destitution, and consequent disease, which are now desolating large areas in Ireland and in the Highlands and Islands of Scotland, we cannot permit the present session of the Legislature to close, without an expression of their sympathy with the numerous sufferers under the present calamity, and without an attempt, commensurate in some degree with the ability of the Colony, to aid the benevolence of our fellow colonists and fellow subjects throughout the empire, now so actively and admirably exerted for their relief. ${ }^{68}$

A number of Baptist Chapels in the Bahamas contributed to Irish relief, their congregations comprising of large numbers of former black slaves. ${ }^{69}$ This generosity

\footnotetext{
${ }^{67}$ Earl of Elgin to Earl Grey, 28 May 1847, 'Copies of despatches addressed to the Secretary of State from the Governor of Her Majesty's colonial possessions relative to money voted and subscriptions raised for the Relief of the destitute Poor in Ireland and Scotland', in Papers Relative to the Relief of the Destitute Poor in Ireland and Scotland 1847 (Copies of despatches), 1847, vol. 53, p. 7.

${ }^{68}$ Ibid., Enclosure in No. 9, Governor Mathew, Government House Nassau to Earl Grey, 8 April 1847, p. 12.

${ }^{69}$ James Martin WRIGHT, History of the Bahama Islands, with a special study of the abolition of slavery in the colony, New York: Macmillan Co., 1905, p. 542.
} 
was replicated elsewhere. When forwarding $£ 310.3 \mathrm{~s} .5 \mathrm{~d}$. from the small island of Tobago, the Governor explained:

\begin{abstract}
Although this is only a mite compared in comparison with the gigantic efforts made by the richer provinces for the relief of our destitute fellow countrymen, Your Lordship will learn with pleasure that the negro population of Tobago have come forward on this occasion with much liberality and good feeling. ${ }^{70}$
\end{abstract}

Donations to the British Association came from all over Europe. Numerous contributions were made in France, which had historical, political and religious links with Ireland. In the spring of 1847, an old and feeble Daniel O'Connell was travelling through the country, en route to see the Pope. ${ }^{71}$ Like Britain, France was also in the midst of an industrial downturn, while a poor harvest had resulted in a number of food protests. ${ }^{72}$ Regardless, multiple donations were made to Ireland via the British Association, coming from diverse origins. N. Johnston and Sons, china merchants in Bordeaux, sent $£ 217.2 \mathrm{~s} .8 \mathrm{~d}$. One of the owners, David Johnston, was the adopted son of a successful Irish merchant. David had been the local Mayor from 1838 to $1842 .{ }^{73}$ The Johnston family was also famous for its wine cellar, which was described by a travel writer visiting the region as ' $a$ subterraneous wonderland' ${ }^{74}$ English residents in Caen gave $£ 17$, with a local church raising a further $£ 11$. The English Congregation at Avanches, also in Normandy, sent $£ 50$. A collection of $£ 17$ was made at Lisieux. The British Church in Dieppe raised $£ 12$ at an Offertory made during Lent. An anonymous donation of ten shillings from "G.S." was sent via the British Consul in Calais. British residents in Marseilles gave $£ 71.1 \mathrm{~s}$. The Catholic Order of the Holy Sepulchre in Paris sent $£ 21.11$ s.3d. The Anglican congregation of St Servin, situated near to St Malo in western France, collected £72, which they sent via their English-born minister, the Rev. Samuel Symons. ${ }^{75}$ Trustees of the British Protestant Church in Le Havre gave £91. Messrs Lafitte, Blount and Company in Paris sent a remittance of $£ 259.17$ s.11d. A few years earlier, Edward Blount, an Irishman, had helped O'Connell set up the Provincial Bank in Ireland, assisted by the Anglo-Jewish banker, Moses Montefiore. ${ }^{76}$ British residents in Pau in the south of France contributed $£ 295.5 \mathrm{~s}$.6d. following a sermon given by their Anglican chaplain, the Rev. E. Hedges. Hedges was an admirer of the evangelical preacher, Rev. Alexander Dallas, who had established a number of proselytizing

70 'Copies of despatches', Lieutenant Governor Graeme, Government House, Tobago, to Earl Grey, 4 May 1847, p. 15.

${ }^{71}$ O'Connell never made it to Rome, dying in Genoa on 15 May 1847. His final speech in the House of Commons (8 February) had been a plea on behalf of the starving Irish.

72 'The Food Riots in France', London Standard, 21 January 1847.

73 'Rue David Johnston' in Bordeaux is named after him. See: $<$ http://bordeaux.360cityscape. com/rue-david-johnston/266/> [accessed 15 May 2013].

${ }^{74}$ Charles COCKS, Bordeaux: its wines, and the claret country, London: Longman, Brown and Green, 1846, p. 6.

${ }^{75}$ George Clement BOASE and William Prideaux COURTNEY, Bibliotheca Cornubiensis, P-Z, London: Longmans, Green, Reader and Dyer, 1874-82, p. 697.

${ }^{76}$ The Blount Bank, Father and Son, established in the 1830s, was situated on Lafitte Street in Paris; Sir Edward Charles BLOUNT, Memoirs of Sir Edward Blount, New York: Arno Press, 1977, pp. 44, 102. 
missions in the west of Ireland..$^{77}$ Hedges subsequently made contributions to the Irish Church Mission Society for the Conversion of Catholics. ${ }^{78}$ In France, as elsewhere, therefore, donations cut across religious and social divides, with motives for giving to the Association varying.

\section{The Poor helping the Poor}

A high proportion of contributions came from people who were themselves poor, with little disposable income. While the amounts they gave to the British Association appeared small in monetary terms, relative to disposable income, they represented a real sacrifice. Examples include workers on the Aberdare Railway in Wales who gave $£ 28$, employers in the London lathe-making firm of Holtzapffel \& Co. raised $£ 1.11$ s, while 'Day Labourers on a property of a resident landowners' in Crosby Ravensworth near Appleby in Cumbria, donated £6.3s.

A number of donations to the British Relief Association came from groups who, like the Irish poor, were themselves marginalized - and sometimes even demonized - within early Victorian society. Two contributions came from Pentonville, a Home for Penitent Females in London, which had been opened in 1807 as a charity, 'intended to save those whom the vanity, idleness, and the treachery of man have led astray ${ }^{79}$ A fast by the inmates raised $£ 1.1$ s., while the officers collected $£ 8.17 \mathrm{~s}$ for the British Association. Similar sacrifices were made by other impoverished groups. A fast in an unidentified Foundling Hospital raised $£ 202$. The cruelty of this and similar institutions had been immortalized only few years earlier by Charles Dickens in Oliver Twist, published in $1838 .{ }^{80}$

In November 1845, in the wake of the first appearance of the potato blight, the then Prime Minister, Sir Robert Peel, had warned:

There will no hope of contributions from England for this calamity. Monster meetings, the ungrateful return for past kindness, the subscriptions in Ireland to the Repeal rent and the O'Connell tribute, will have disinclined the charitable here to make any great exertions for Irish relief. ${ }^{81}$

Peel was not alone in this opinion. At the end of December 1846, as the British Association was starting its work, Trevelyan confided to Lord John Russell, 'Feeling in London is so strong against the Irish that I doubt much progress will be

\footnotetext{
${ }^{77}$ See KINEALY, Kindness, op. cit., pp. 270-75.

${ }^{78}$ Society for Irish Church Missions to the Roman Catholics, The banner of the truth in Ireland: monthly information concerning Irish Church Missions to the Roman Catholics, London: Wonston, 1852, p. 26.

79 'Pentonville' in Walter THORNBURY, Old and New London: a narrative of its history, its people, and its places, London: Cassell, Petter and Galpin, 1878, pp. 279-289.

${ }^{80}$ Dickens lived next to, and supported financially, the Foundling Hospital at 48 Doughty Street, London - now the Charles Dickens Museum.

${ }^{81}$ Cabinet Memorandum, 1 November 1845, quoted in Lord MAHON and Hon. Sir Edward CARSWELL (eds), Memoirs of Sir Robert Peel, London: John Murray, 1857, p. 145.
} 
made in London in subscriptions until further horrifying accounts are received'. ${ }^{82}$ Overall, the donations to the British Association that came from Britain and other parts of the British Empire reveal the complexity of Ireland's colonial position. Views of Ireland as subversive and dangerous to the British imperial mission, and of the Irish poor as lazy and undeserving, appeared forgotten as this humanitarian tide gained momentum in 1847. The charitable impulse was short-lived and, despite the best intentions of the British Association, the Society of Friends, and the thousands of donors who made their work possible, over one million people died in the space of six years. As Strzelecki and the Quakers realized, charity alone could not alleviate the structural problems arising from hundreds of years of mis-government of Ireland.

\section{Conclusion}

As was the case with other charities, donations to the British Association were concentrated in the early months of 1847 , with income drying up when the new harvest became available. The fact that the potato crop was relatively blight-free contributed to the mistaken belief that the famine was over. When the British Association formally suspended its work in Ireland in the summer of 1848, they had raised over $£ 470,000$ - far more than any other relief organization. Since October 1847 , they had provided $£ 150,000$ to supplement the work of the Poor Law. Importantly also, they had, at the urging of Strzelecki, fed the children of the poor.

The ending of the involvement of Strzelecki and the British Relief Association was lamented widely. The Poor Law Commissioners, whose work after 1847 would not have been possible without the financial support of the Association, keenly felt the loss. When thanking Strzelecki, they pointed out: 'It must be a source of true and reined pleasure to your benevolent mind, to know that your exertions on behalf of the poor children have been attended with even more than that measure of success which could have been anticipated. ${ }^{83}$ They also acknowledged that his duties had required 'great labour and anxiety, and a considerable degree of personable risk, ${ }^{84}$

In 1848, it was announced that Trevelyan was to be knighted, and would receive a salary bonus for his work during the Famine. ${ }^{85}$ Strzelecki was knighted some months later, which the Morning Chronicle described as being 'somewhat tardily', observing: 'The labour, the ability and the deserts of Count Strzelecki were, to say the least, in no degree inferior to those of Mr Trevelyan. Moreover, they were voluntary and gratuitous, and they involved much personal danger and discomfort. $^{, 86}$

\footnotetext{
${ }^{82}$ Quoted in Cecil WOODHAM-SMITH, The Great Hunger, Ireland 1845-49, New York: Harper, 1963, p. 169.

${ }^{83}$ Poor Law Commissioners to Strzelecki, 27 July 1848, Papers relating to proceedings for relief of distress, and state of unions and workhouses in Ireland, BPP, 1847-1848, vol. 54, pp. 3-4.

${ }^{84}$ Ibid.

${ }^{85}$ Morning Chronicle, 28 November 1848.

${ }^{86}$ Ibid.
} 
In 1849 , when suffering and starvation showed no signs of abating in parts of Ireland, Strzelecki was asked to travel to the west on a fact-finding mission. Despite his experience, he was shocked by the condition of the poor in receipt of Poor Law relief, they being 'in a state of emaciation, sickness and nudity hardly credible, crowding together and crouching under heaps of rotten straw of their unroofed cabins, under bridges, burrowing on the roadside, or in the ditches of the cold and wet bogs ${ }^{87}$ In the same year, Strzelecki gave evidence before a government select committee on the Poor Laws. In his responses he was unequivocal that 'the calamity which has befallen to Ireland is an Imperial calamity' ${ }^{88}$ Moreover, "people in the British Empire, as long as that empire possesses any means, should not be allowed to die from starvation'. ${ }^{9}$

Strzelecki died at his home in London in 1873. He was aged 77. His death was noted in newspapers in Britain, Poland and Australia, but passed with little notice in Ireland. ${ }^{90}$ Yet, according to an early historian of the Famine, William O'Brien, Strzelecki was not forgotten in Ireland, and within the west 'the name of this benevolent stranger was then, and for long afterwards, a familiar one if not a household word, in the homes of the suffering poor'. Strzelecki had not only given relief to the poor of Ireland, he had also given them dignity and respect, and he had been their tireless champion in the cold-hearted corridors of Whitehall and Westminster. However, his work would not have been possible without the quiet support and hard work of the committee of bankers that met in Threadneedle Street. That these men have largely been written out of Famine historiography is, according to Irish historian Timothy P. O'Neill, because of understandable anger with the British government, and because 'bitterness moulded Irish politics in the succeeding years.91

In monetary terms, the British Relief Association was the charitable organization that raised the largest amount of money during the Famine. What this meant in terms of saving lives, and providing comfort to a desperate people, cannot be measured numerically. The distribution of charitable donations was only possible due to the selfless sacrifices of numerous, now largely forgotten, individuals. A Polish man, Paul de Strzelecki, was the most remarkable member of this group. Without their dedication and hard-work on behalf of the Irish poor, especially the children, the catastrophic loss of life during the Great Famine would have been even higher. Moreover, these forgotten heroes not only saved lives, they provided a humanitarian light in a desert of ideological darkness.

\footnotetext{
${ }^{87}$ Nation, 27 October 1849.

${ }^{88}$ Evidence of Strzelecki, 4 May 1849, Select Committee of House of Lords to Inquire into the operation of the Irish Poor Law, BPP, 1849, vol. 16, qu. 8637.

${ }^{89}$ Ibid., qu. 8638.

${ }^{90}$ South Australian Advertiser, 26 December 1873.

${ }^{91}$ O'Neill was writing in 1995 and since then a new generation of scholars has contributed to a more nuanced view of the Famine. Nonetheless, the role of private charity in general, and the British Relief Association in particular, remains under-researched. Timothy P. O'NEILL, 'The Great Irish Famine, 1845-52', Old Limerick Journal, vol. 32, Winter 1995, p. 20.
} 


\section{Bibliography}

Baring Archives, London, HC 15 A. 2, 1846-48.

BLOUNT, Sir Edward Charles. Memoirs of Sir Edward Blount. New York: Arno Press, 1977.

BOASE, George Clement and William Prideaux COURTNEY. Bibliotheca

Cornubiensis, P-Z. London: Longmans, Green, Reader and Dyer, 1874-82.

British Parliamentary Papers:

Correspondence relating to the measures adopted for the relief of the distress in Ireland, Jan. to March 1847. 1847, vol. 52.

Papers Relative to the Relief of the Destitute Poor in Ireland and Scotland. 1847, vol. 53.

Papers relating to proceedings for relief of distress, and state of unions and workhouses in Ireland. 1847-1848, vol. 54.

Select Committee of House of Lords to Inquire into the operation of the Irish Poor Law. 1849, vol. 16.

COCKS, Charles. Bordeaux: its wines, and the claret country. London: Longman, Brown and Green, 1846.

DUFFERIN, Frederick Temple Blackwood. Narrative of a Journey from Oxford to Skibbereen during the Year of the Irish Famine. Oxford: John Henry Parker, 1847.

EASTON, Harry Tucker. The history of a banking house: Smith, Payne and Smiths. London: Blades, East \& Blades, 1901.

FERGUSON, Niall. The House of Rothschild: Money's prophets, 1798-1848. London: Penguin, 1999.

GRAY, Peter. 'National Humiliation and the Great Hunger: Fast and Famine in 1847’, Irish Historical Studies, Vol. 32, No. 126, Nov. 2000, pp. 193-216.

HYAMSON, Albert Montefiore, David Salomons. London: Methuen, 1939.

KINEALY, Christine. A Death Dealing Famine. The Great Hunger in Ireland. London: Pluto Press, 1997.

Charity and the Great Hunger in Ireland: The Kindness of Strangers.

London: Bloomsbury, 2013.

London Standard.

MAHON, Lord and Hon. Sir Edward CARSWELL (eds). Memoirs of Sir Robert Peel. London: John Murray, 1857.

Minutes of the British Relief Association, National Library of Ireland, Ms. 2022.

Monteagle Papers, National Library of Ireland, Ms. 13,395.

Morning Chronicle (London).

Nation (Dublin). 
O'CONNELL, Daniel. Daniel O'Connell: His Early Life, and Journal, 1795 to 1802. London: Pitman and sons, 1906.

Ó GRÁDA, Cormac. Ireland Before and After the Famine: Explorations in Economic History, 1800-1925. Manchester University Press, 1993.

O’NEILL, Timothy P. 'The Great Irish Famine, 1845-52', Old Limerick Journal, Vol. 32, Winter 1995, pp. 16-20.

PALLISER, John. Solitary rambles and adventures of a hunter in the prairies. London: J. Murray, 1853.

RAWSON, Geoffrey. The Count. A Life of Sir Paul Edmund Strzelecki, K.C.M.G. Explorer and Scientist. Melbourne: William Heinemann, 1953.

Report of the Deputation Appointed by the Honorable the Irish Society to Visit the City of London's Plantation in Ireland in the Year 1836. London: C. Skipper and East, 1836.

Report of British Relief Association for the Relief of Distress in Ireland and the Highlands of Scotland. London: Richard Clay, 1849.

RIDDING, Lady Laura. George Ridding: schoolmaster and bishop, forty-third head master of Winchester, 1866-1884, first bishop of Southwell, 1884-1904. London: E. Arnold, 1908.

Lord John Russell Papers. National Archives of England, T.64/367 B.

SINGER, Isidore and Cyrus ADLER. The Jewish Encyclopedia: A Descriptive Record of the History, Religion, Literature, and Customs of the Jewish People from the Earliest Times to the Present Day. New York and London: Funk and Wagnalls, vol. 10, 1916.

Society for Irish Church Missions to the Roman Catholics. The banner of the truth in Ireland: monthly information concerning Irish Church Missions to the Roman Catholics. London: Wonston, 1852.

South Australian Advertiser.

THORNBURY, Walter. Old and New London: a narrative of its history, its people, and its places. London: Cassell, Petter and Galpin, 1878.

THUMB, Tom. Sketch of the life: personal appearance, character and manners of Charles S. Stratton, the man in miniature, known as General Tom Thumb, and his wife, Lavinia Warren Stratton, including the history of their courtship and marriage... New York: S. Booth, 1874.

Times (London).

Tuam Herald (Galway).

Tyrawly Herald (Mayo).

Western Times (Devon).

WOODHAM-SMITH, Cecil. The Great Hunger, Ireland 1845-49. New York: Harper, 1963.

WRIGHT, James Martin. History of the Bahama Islands, with a special study of the abolition of slavery in the colony. New York: Macmillan Co., 1905. 